\title{
EREG wt Allele
}

National Cancer Institute

\section{Source}

National Cancer Institute. EREG wt Allele. NCI Thesaurus. Code C51422.

Human EREG wild-type allele is located in the vicinity of $4 q 13.3$ and is approximately $24 \mathrm{~kb}$ in length. This allele, which encodes epiregulin protein, is involved in tyrosine-kinase signal transduction. 